CASSOWARY volume 5 (1) Januari 2022: 22 - 34

ISSN : 2614-8900

E-ISSN : 2622-6545

Program Pascasarjana Universitas Papua, https://pasca.unipa.ac.id/

\title{
Karakteristik limbah medis padat dan pengelolaannya di Rumah Sakit Umum Daerah Manokwari
}

\author{
Ria Maria Come ${ }^{1}$, Zita L. Sarungallo ${ }^{1}$, M. Meilan Lisangan ${ }^{1 *}$ \\ Program Studi Ilmu Lingkungan, Program Pascasarjana, Universitas Papua, Jalan \\ Gunung Salju, Amban, Manokwari, Papua Barat, 98314, Indonesia \\ *Email: mml.talakua@gmail.com
}

Disubmit: 16 Maret 2021, direvisi: 30 Desember 2021, diterima: 10 Januari 2022

Doi: https://doi.org/10.30862/casssowary.cs.v5.i1.95

\begin{abstract}
Garbage is a waste or a byproduct of a business process or activity that is wasted negatively on living things and the environment. Solid medical waste can cause nosocomial infections. The aim of this research is to study the information on solid medical waste generated in Manokwari Hospital activities and medical stages based on the Republic of Indonesia Minister of Health Decree number 1204/MENKES/SK/X 12004. This research method is a qualitative descriptive study, using descriptive methods with survey techniques and observation. The waste observed in this study was solid medical waste generated from hospital activities, solid medical waste in the form of used syringes with an average value of $2.14 \mathrm{~kg}$ and bottles with an average value of $1.97 \mathrm{~kg}$ and gauze with an average value. -average $1.48 \mathrm{~kg}$. The stages of medical waste management at Manokwari Hospital start from sorting, related, transporting, storing and destroying.
\end{abstract}

Keywords: RSUD Manokwari, solid medical waste management

\section{PENDAHULUAN}

Rumah Sakit Umum Daerah Manokwari (RSUD) merupakan pusat pelayanan kesehatan masyarakat yang kegiatannya menghasilkan berbagai limbah medis padat dan limbah medis cair. Selain itu, kurangnya kesadaran masyarakat dan pasien dalam hal kebersihan juga menambah sulitnya pengelolaan sampah dirumah sakit (Jumriah et al., 2021). Rumah sakit ini tergolong rumah sakit tipe $\mathrm{C}$ dengan fasilitas/sarana medis \pm 174 tempat tidur. RSUD dapat menghasilkan limbah padat medis sebesar $3 \mathrm{~kg}-562$ $\mathrm{kg}$ perhari. Lama penyimpanan limbah medis padat yang dihasilkan oleh fasilitas kesehatan RSUD Manokwari lebih dari 48 jam dan pemusnahannya di incinerator kurang lebih 2 kali/minggu, dapat pula $1 \mathrm{kali} / \mathrm{bulan}$.

Limbah medis atau klinis mencakup semua hasil buangan yang berasal dari instalasi kesehatan, fasilitas penelitian dan laboratorium. Limbah medis padat dapat menyebabkan kasus nosokomial, yaitu infeksi yang terjadi di rumah sakit. Rumah sakit yang sanitasi lingkungannya tidak memenuhi standar KEPMENKES RI No. 1204 tahun 2004 akan meningkatkan kasus nosokomial. Berdasarkan profil kesehatan Indonesia Departemen Kesehatan RI (2004) dari keseluruhan perawatan kesehatan pada 
beberapa rumah sakit di negara-negara berkembang didapatkan variasi jumlah total limbah padat sebesar 0,016 -3,23 $\mathrm{kg} / \mathrm{tempat}$ tidur per hari. Sejauh ini, kondisi limbah medis padat terkait timbunan, komposisi dan pengelolaannya belum pernah dilaporkan. Oleh sebab itu penelitian ini perlu dilakukan untuk mengkaji kondisi limbah medis padat yang dihasilkan oleh RSUD Manokwari.

Penelitian ini bertujuan untuk mengetahui karakteristik timbulan dan tahapan pengelolaan limbah medis padat di RSUD Manokwari berdasarkan Kepmenkes RI Nomor 1204/MENKES /SK/X/2004. Hasil penelitian ini diharapkan dapat menjadi masukkan kepada pihak RSUD Kabupaten Manokwari maupun pihak-pihak terkait agar dalam proses pengelolaan limbah, terutama limbah padat yang berasal dari Rumah Sakit.

\section{METODE}

Penelitian ini merupakan jenis penelitian deskriptif kualitatif, menggunakan metode deskriptif dengan teknik survei dan observasi. Adapun observasi dilakukan yakni observasi tahapan pengelolaan limbah medis padat pada RSUD Manokwari. Penelitian ini dilaksanakan selama 2 (dua) bulan, yaitu pada bulan Februari Maret.

Jenis data dalam penelitian ini berupa data primer dan data sekunder. Data primer diperoleh dari pengisian kuisioner responden kunci dan responden lainnya (Wawan, 2010), observasi langsung pada ruanganruangan penghasil limbah medis padat serta tahapan pengelolaan limbah medis padat di RSUD Manokwari. Data sekunder diperoleh dari Profil Rumah Sakit Umum Daerah Manokwari, Standar Operasional Prosedur (SOP) RSUD Manokwari, dan data jumlah pasien yang berkunjung (Sulistionigsih, 2014).

Analisis timbulan limbah dilakukan dengan mengacu pada SNI 19-3964-1994 sebagai berikut:

1. Menentukan lokasi pengambilan dan membagikan trash bag bagi kepada sumber penghasil limbah medis padat sehari sebelum dikumpulkan

2. Pada hari pengumpulan, trash bag yang telah terisi limbah medis padat dikumpulkan.

3. Seluruh trash bag diangkut ke tempat pengukuran dan limbah yang telah terkumpul dipilah berdasarkan komposisinya pada setiap sumber penghasil

4. Penimbangan bak pengukur $40 \mathrm{~L}$ (VI)

5. Masing-masing komposisi limbah yang telah terpilah dimasukan ke dalam bak pengukur $40 \mathrm{~L}$

6. Bak pengukur dihentak sebanyak 3 kali dengan mengangkat setinggi 20 $\mathrm{cm}$ lalu di jatuhkan. ukur dan catat Volume limbah medis padat (V2) diukur dan dicatat nilainya.

7. Masing-masing komposisi limbah medis padat selanjutnya ditimbang dan dicatat berat dan Volumenya dengan rumus V2-V1

8. Persentase tiap komponen limbah medis padat dihitung dengan persamaan:

$$
\begin{aligned}
& \% \text { Satu Komponen = } \\
& \underline{\text { Berat limbah Satu Komponen }(\mathrm{kg}) \times 100} \\
& \text { Berat limbah Total }
\end{aligned}
$$

Tahap pengelolaan limbah medis padat diobservasi berdasarkan SOP dari RSUD Manokwari yang mengacu pada Kepmenkes RI Nomor 1204/MENKES/SK/X/2004.

Variabel yang diamati adalah timbulan limbah medis padat, karakteristik limbah, dan tahap pengelolaan limbah (Nursamsi, et. al., 
2017). Hasil penelitian dianalisis secara deskriptif kuantitatif.

\section{HASIL DAN PEMBAHASAN}

\section{Karakteristik Timbulan Limbah \\ Medis Padat}

Limbah rumah sakit merupakan limbah yang dihasilkan dari pelayanan medis berupa limbah yang berbentuk padat, cair dan gas yang semuanya dapat mengandung mikrooganisme pathogen yang bersifat infeksius serta bahan bahan kimia beracun yang sebagian mengandung bahan radioaktif (Chotijah et al, 2017). Proses pengelolaan pada ketiga jenis limbah medis padat ini juga berbeda. Komponen limbah medis padat dapat di lihat pada Tabel 1.

Jenis limbah medis padat yang terdiri dari bahan kaca, botol plastik dan botol infus, botol kaca bekas obat/bahan kimia dan sejenisnya (golongan A) dimasukkan dalam kantong plastik berwarna kuning (Zuhriyani, 2019). Limbah medis padat yang bersifat tajam seperti jarum suntik, jarum infus, medicate, pinset, spuit, pisau/silet, ampul, lanset dan sejenisnya (golongan B) dimasukkan dalam kotak karton (safety box) atau dimasukkan dalam ember yang telah dimodifikasi. Limbah medis lunak (basah dan kering) seperti perban, kapas, pembalut, plastik, kain berdarah/hand skon, grenjeng obat, kateter/tempat penampung urin, spet dan sejenisnya (golongan C) dimasukkan dalam kantong plastik berwarna merah (WHO, 2005). Sedangkan untuk limbah non medis dibuang ke dalam tempat sampah yang dilapisi kantong plastik hitam dan berlabel non medis.

\section{Timbulan Limbah Medis Padat}

Timbulan sampah adalah banyaknya sampah yang dihasilkan per hari atau per luas ruangan SNI (1994). Faktor yang mempengaruhi timbulan limbah medis padat rumah sakit maupun puskesmas antara lain adalah tingkat hunian, jenis pelayanan kesehatan yang diberikan, status ekonomi, sosial dan budaya pasien serta letak geografis (Askarian et al, 2004). Faktor tersebut juga akan berpengaruh pada timbulan limbah medis padat yang dihasilkan per unit ruangan pada RSUD Manokwari, yaitu mengenai jumlah pasien atau tingkat hunian pasien yang di rawat pada masing-masing unit ruangan.

Tabel 1. Komponen Limbah Medis Padat berdasarkan Unit Ruangan

\begin{tabular}{cllc}
\hline No & \multicolumn{1}{c}{ Unit Ruangan } & Komponen Limbah & Golongan Limbah \\
\hline 1 & Ruang Instalasi Gawat Darurat (IGD) & Jarum, Botol dan Kasa & A, B, C \\
2 & Ruang Bedah & Jarum, Botol dan Kasa & A, B, C \\
3 & Ruang RPD Melati & Jarum, Botol dan Kasa & A, B, C \\
4 & Ruang Bersalin & Jarum, Botol dan Kasa & A, B, C \\
5 & Ruang Poli Bedah & Jarum, Botol dan Kasa & A, B, C \\
6 & Ruang Perinatologi & Jarum, Botol dan Kasa & A, B, C \\
7 & Ruang Gardenia/Anak & Jarum, Botol dan Kasa & A, B, C \\
8 & Ruang Laboratorium & Jarum, Botol dan Kasa & A, B, C \\
9 & Ruang Kamar Operasi & Jarum, Botol dan Kasa & A, B, C \\
10 & Ruang VIP Dewasa & Jarum, Botol dan Kasa & A, B, C
\end{tabular}

Keterangan golongan limbah medis padat: $\mathrm{A}=\mathrm{J}$ arum; $\mathrm{B}=$ Botol; $\mathrm{C}=$ Kasa

Sumber: Data primer (2019) 
Data yang berhasil diperoleh menunjukkan bahwa penggunaan jarum, kasa dan botol mengalami peningkatan yang tidak menentu serta bergantung pada jumlah pasien yang masuk pada tiap-tiap ruangan. Pada proses pelayanan kesehatan di Rumah Sakit, tidak dapat terlepas dari penggunaan jarum suntik, kerena proses ini merupakan salah satu alternative terbaik yang ada hingga saat ini. Menurut van Tuong dkk (2017), injeksi merupakan metode medis yang paling sering digunakan untuk memperkenalkan obat atau zat ke dalam tubuh untuk tujuan pengobatan. Pada penggunaan jarum untuk setiap unit ruangan berdasarkan hasil pengamatan kehadiran pasien per unit ruangan yang dihubungkan dengan jenis dan berat limbah selama 2 bulan menunjukan variasi berat limbah yang cukup beragam yang diperlihatkan pada Tabel 2-4.

\section{Limbah Jarum}

Limbah medis jarum dimasukkan ke dalam golongan benda tajam, yaitu alat/objek yang memiliki sudut tajam atau bagian yang memiliki sudut tajam atau bagian yang menonjol yang dapat memotong atau merusak kulit seperti jarum hipodermik dan perlengkapan intravena (Djohan dan Halim, 2013). Limbah medis padat jarum yang dihasilkan berdasarkan unit setiap ruangan di RSUD Manokwari memiliki peningkatan yang cukup tinggi selama pengamatan berlangsung (Tabel 2).

Tabel 2. Limbah Jarum yang Dihasilkan dari Setiap Ruangan berdasarkan Minggu Pertama Hingga Minggu Keempat

\begin{tabular}{|c|c|c|c|c|c|c|c|c|}
\hline \multirow{2}{*}{ No } & \multirow{2}{*}{ Ruangan } & \multicolumn{4}{|c|}{ Minggu } & \multirow{2}{*}{$\begin{array}{l}\text { Jumlah/(Kg) } \\
\text { per ruangan }\end{array}$} & \multirow{2}{*}{$\begin{array}{c}\text { Rata- } \\
\text { rata } \\
(\mathrm{Kg})\end{array}$} & \multirow{2}{*}{ Keterangan } \\
\hline & & $\mathbf{I}$ & II & III & IV & & & \\
\hline 1 & $\begin{array}{l}\text { Unit Gawat } \\
\text { Darurat (UGD) }\end{array}$ & 3,1 & 2,6 & 2,5 & 1,9 & 10,1 & 2,5 & $\begin{array}{l}\text { Bekas } \\
\text { digunakan }\end{array}$ \\
\hline 2 & Ruang Bedah & 2,3 & 1,8 & 2,4 & 2,1 & 8,6 & 2,2 & $\begin{array}{l}\text { Bekas } \\
\text { digunakan }\end{array}$ \\
\hline 3 & $\begin{array}{l}\text { Ruang penyakit } \\
\text { dalam/Melati }\end{array}$ & 2,7 & 2,9 & 3,0 & 3,4 & 12 & 3 & $\begin{array}{l}\text { Bekas } \\
\text { digunakan }\end{array}$ \\
\hline 4 & Ruang Bersalin & 2,4 & 1,9 & 1,6 & 1,8 & 7,7 & 2 & $\begin{array}{l}\text { Bekas } \\
\text { digunakan }\end{array}$ \\
\hline 5 & $\begin{array}{l}\text { Ruang Poli } \\
\text { Bedah }\end{array}$ & 1,6 & 1,6 & 1,4 & 1,6 & 6,2 & 1,6 & $\begin{array}{l}\text { Bekas } \\
\text { digunakan }\end{array}$ \\
\hline 6 & $\begin{array}{l}\text { Ruang } \\
\text { Perinatologi }\end{array}$ & 2,5 & 1,6 & 1,5 & 1,4 & 7 & 1,7 & $\begin{array}{l}\text { Bekas } \\
\text { digunakan }\end{array}$ \\
\hline 7 & $\begin{array}{l}\text { Ruang } \\
\text { Gardenia/Anak }\end{array}$ & 2,3 & 2,3 & 2,8 & 1,8 & 9,2 & 2,3 & $\begin{array}{l}\text { Bekas } \\
\text { digunakan }\end{array}$ \\
\hline 8 & $\begin{array}{l}\text { Ruang } \\
\text { Laboratorium }\end{array}$ & 3,0 & 2,4 & 1,4 & 1,7 & 8,5 & 2,1 & $\begin{array}{l}\text { Bekas } \\
\text { digunakan }\end{array}$ \\
\hline 9 & Kamar Operasi & 2,7 & 2,6 & 1,7 & 1,9 & 8,9 & 2,2 & $\begin{array}{l}\text { Bekas } \\
\text { digunakan }\end{array}$ \\
\hline 10 & $\begin{array}{l}\text { Ruang VIP } \\
\text { Dewasa }\end{array}$ & 1,7 & 1,6 & 2,1 & 2,0 & 7,4 & 1,8 & $\begin{array}{l}\text { Bekas } \\
\text { digunakan }\end{array}$ \\
\hline \multicolumn{2}{|c|}{$\begin{array}{l}\text { Jumlah (Kg) per } \\
\text { minggu }\end{array}$} & 24,30 & 21,30 & 20,40 & 19,60 & 85,6 & 21,4 & \\
\hline \multicolumn{2}{|c|}{$\begin{array}{l}\text { Rata-rata ruangan } \\
\text { (Kg) per minggu }\end{array}$} & 2,43 & 2,13 & 2,04 & 2 & 8,56 & 2,14 & \\
\hline
\end{tabular}

Sumber: Data primer (2019) 
Data Tabel 2 menunjukkan bahwa berat limbah medis padat (jarum) yang dihasilkan dari sepuluh ruangan, ditemukan Ruang Penyakit Dalam/Melati yang menghasilkan limbah jarum dengan berat total tertinggi $12 \mathrm{~kg}$. Banyaknya limbah jarum pada ruangan ini disebabkan karena proses penangan pasien lebih banyak menggunakan jarum suntik sekali pakai. Selain itu perkembangan ilmu pengetahuan dan teknologi juga mengharuskan petugas medis untuk menggunakan jarum suntik sekali pakai (disposable) dalam menangani pasien (Biro Umum dan Setjen Depkes RI, 2003). Sedangkan limbah medis padat jarum paling sedikit ditemukan pada ruangan poli bedah yaitu sebanyak 6,2 $\mathrm{kg}$, Hal ini disebabkan karena proses penanganan pasien lebih sedikit dan kurang menggunakan jarum suntik.

Jarum merupakan limbah benda tajam yang termasuk ke dalam golongan B. Semua benda tajam dalam golongan B memiliki potensi yang berbahaya untuk menularkan penyakit karena terkontaminasi dengan darah, cairan tubuh, bahan mikrobiologi dan beracun, bahan sitoktoksit atau radioaktif (Djohan dan Halim, 2013). Pengelolaan pada limbah ini dilakukan dengan melakukan pengumpulan pada tempat sumber penghasil limbah, pengangkutan, penyimpanan atau penampungan, serta pemusnahan melalui insenerator (Widiartha, 2012). Menurut Hapsari (2010) limbah medis padat seperti syringe, jarum dan cartridges merupakan jenis limbah golongan B yang hendaknya dibuang dalam keadaan tertutup, serta limbah jenis ini sebaiknya ditampung dalam penampungan yang dapat tahan terhadap benda tajam sebelum diangkut dan dimusnahkan menggunakan insenerator (Rusdiana, et al., 2014). Dalam penanganan jenis limbah medis padat jarum di RSUD Manokwari, dikumpulkan menggunakan safety box dan modifikasi ember cat yang dilapisi kantong plastik kuning telah mengikuti SOP yang berlaku yaitu dengan menampung sebelum dimusnahkan menggunakan insenerator.

\section{Limbah Botol}

Dalam pelayanan kesehatan di rumah sakit, limbah medis padat seperti botol banyak bersumber dari unit-unit ruangan seperti ruang poliklinik, ruang perawatan dan penyembuhan, ruang laboratorium, serta ruang farmasi atau kimia (Sitopu, 2017). Pengamatan terhadap limbah medis padat berupa botol yang dilakukan berdasarkan unit ruangan di RSUD Manokwari dapat dikategorikan cukup tinggi seperti pada Tabel 3.

Data pada Tabel 3 menunjukkan bahwa limbah medis padat berupa botol terbanyak dihasilkan pada ruangan penyakit dalam dengan jumlah $12,4 \mathrm{~kg}$. Sedangkan ruangan yang menghasilkan limbah medis padat botol yang terendah adalah pada ruangan perinatologi sebanyak 6,1 kg. Data tersebut menunjukkan bahwa penanganan pasien rawat inap lebih banyak menggunakan obat dalam kemasan botol dan penggunaan botol ini lebih banyak berhubungan dengan terapi intravena atau infus. Terapi ini merupakan salah satu cara untuk memperbaiki atau mencegah ketidak seimbangan cairan dalam tubuh pasien, sehingga pada setiap ruangan di RSUD Manokwari juga banyak menggunakan botol dalam melakukan infus dan meningkatkan peningkatan pada limbah medis padat yang berasal dari botol. 
Tabel 3. Limbah Botol yang Dihasilkan dari Setiap Ruangan Berdasarkan Minggu Pertama Hingga Minggu Keempat

\begin{tabular}{|c|c|c|c|c|c|c|c|c|}
\hline \multirow[b]{2}{*}{ No } & \multirow{2}{*}{ Ruangan } & \multicolumn{4}{|c|}{ Minggu } & \multirow{2}{*}{$\begin{array}{l}\text { Jumlah/(Kg) } \\
\text { per ruangan }\end{array}$} & \multirow{2}{*}{$\begin{array}{c}\text { Rata- } \\
\text { rata } \\
(\mathrm{Kg})\end{array}$} & \multirow{2}{*}{ Keterangan } \\
\hline & & I & II & III & IV & & & \\
\hline 1 & $\begin{array}{l}\text { Unit Gawat Darurat } \\
\text { (UGD) }\end{array}$ & 2,8 & 2,6 & 2,1 & 1,5 & 9 & 2,2 & $\begin{array}{l}\text { Bekas } \\
\text { digunakan }\end{array}$ \\
\hline 2 & Ruang Bedah & 2,0 & 2,1 & 1,9 & 1,9 & 7,9 & 2 & $\begin{array}{l}\text { Bekas } \\
\text { digunakan }\end{array}$ \\
\hline 3 & $\begin{array}{l}\text { Ruang penyakit } \\
\text { dalam/Melati }\end{array}$ & 2,6 & 2,7 & 3,5 & 3,6 & 12,4 & 3,1 & $\begin{array}{l}\text { Bekas } \\
\text { digunakan }\end{array}$ \\
\hline 4 & Ruang Bersalin & 2,6 & 1,6 & 1,8 & 1,8 & 7,8 & 1,9 & $\begin{array}{l}\text { Bekas } \\
\text { digunakan }\end{array}$ \\
\hline 5 & Ruang Poli Bedah & 1,5 & 1,4 & 1,5 & 1,3 & 5,7 & 1,4 & $\begin{array}{l}\text { Bekas } \\
\text { digunakan }\end{array}$ \\
\hline 6 & Ruang Perinatologi & 1,9 & 1,4 & 1,4 & 1,4 & 6,1 & 1,5 & $\begin{array}{l}\text { Bekas } \\
\text { digunakan }\end{array}$ \\
\hline 7 & Ruang Gardenia/Anak & 2,3 & 2,0 & 3,0 & 1,7 & 9 & 2,2 & $\begin{array}{l}\text { Bekas } \\
\text { digunakan }\end{array}$ \\
\hline 8 & Ruang Laboratorium & 2,5 & 1,8 & 2,2 & 1,8 & 8,3 & 2,1 & $\begin{array}{l}\text { Bekas } \\
\text { digunakan }\end{array}$ \\
\hline 9 & Kamar Operasi & 1,7 & 1,9 & 1,3 & 1,3 & 6,2 & 1,6 & $\begin{array}{l}\text { Bekas } \\
\text { digunakan }\end{array}$ \\
\hline 10 & Ruang VIP Dewasa & 1,4 & 1,4 & 2,1 & 1,7 & 6,6 & 1,7 & $\begin{array}{l}\text { Bekas } \\
\text { digunakan }\end{array}$ \\
\hline \multicolumn{2}{|c|}{ Jumlah (Kg) per minggu } & 21,30 & 18,90 & 20,80 & 18 & 79 & 19,75 & \\
\hline \multicolumn{2}{|c|}{$\begin{array}{l}\text { Rata-rata ruangan }(\mathrm{Kg}) \\
\text { per minggu }\end{array}$} & 2,13 & 1,89 & 2,08 & 1,8 & 7,9 & 1,975 & \\
\hline
\end{tabular}

Sumber. Data primer (2019)

Berdasarkan pembagian golongan, botol digolongkan ke dalam golongan A dan berdasarkan jenisnya merupakan limbah padat medis non infeksius. Cara pengelolaan limbah ini dilakukan dengan memasukkan kantong plastik berwarna kuning, pengangkutan, penyimpanan dan pemusnahan yang sebelumnya limbah botol disinfeksi dan pemusnahan menggunakan bottle crusher (Rumah Sakit Umum Daerah Manokwari, 2015).

Penggunaan botol juga meningkat pada masing-masing ruangan yang diamati, namun limbah yang dihasilkan ini dapat dikatakan tidak cukup beresiko tinggi menularkan penyakit seperti halnya jarum suntik. Jenis limbah medis padat botol di RSUD Manokwari biasanya langsung di tampung sebelum dimusnahkan menggunakan insenerator, kecuali limbah botol infus (Wicaksana, 2002). Pada pengelolaan limbah medis padat seperti botol, pada saat ini telah mengembangkan sistem Reuse, Reducedan Recycle atau yang dikenal sebagai 3R yang bertujuan untuk meminimalkan limbah padat sebagai bagian dari kunci manajemen lingkungan rumah sakit (Hapsari, 2010). Pemanfaatan botol (infus) yang bisa diolah kembali melalui penampung barang bekas, sehingga tidak menjadi beban kerja pada insenerator.

\section{Limbah Kasa}

Pengamatan yang dilakukan terhadap limbah medis padat kasa berdasarkan unit ruangan penghasil limbah di Rumah Sakit Umum Daerah Manokwari, dapat dilihat pada Tabel 4. 
Tabel 4. Limbah Medis Padat (Kasa) yang Dihasilkan dari Setiap Ruangan berdasarkan Minggu Pertama Hingga Minggu Keempat

\begin{tabular}{|c|c|c|c|c|c|c|c|c|}
\hline \multirow{2}{*}{ No } & \multirow{2}{*}{ Ruangan } & \multicolumn{4}{|c|}{ Minggu } & \multirow{2}{*}{$\begin{array}{l}\text { Jumlah/(Kg) } \\
\text { per ruangan }\end{array}$} & \multirow{2}{*}{$\begin{array}{l}\text { Rata- } \\
\text { rata } \\
(\mathrm{Kg})\end{array}$} & \multirow{2}{*}{ Keterangan } \\
\hline & & I & II & III & IV & & & \\
\hline 1 & $\begin{array}{l}\text { Unit Gawat } \\
\text { Darurat (UGD) }\end{array}$ & 1,9 & 1,4 & 1,6 & 1,3 & 6,2 & 1,6 & $\begin{array}{l}\text { Bekas } \\
\text { digunakan }\end{array}$ \\
\hline 2 & Ruang Bedah & 2,1 & 1,7 & 1,6 & 1,5 & 6,9 & 1,7 & $\begin{array}{l}\text { Bekas } \\
\text { digunakan }\end{array}$ \\
\hline 3 & $\begin{array}{l}\text { Ruang penyakit } \\
\text { dalam/Melati }\end{array}$ & 1,6 & 1,9 & 1,4 & 1,4 & 6,3 & 1,6 & $\begin{array}{l}\text { Bekas } \\
\text { digunakan }\end{array}$ \\
\hline 4 & Ruang Bersalin & 1,7 & 1,5 & 1,3 & 1,4 & 5,8 & 1,5 & $\begin{array}{l}\text { Bekas } \\
\text { digunakan }\end{array}$ \\
\hline 5 & $\begin{array}{l}\text { Ruang Poli } \\
\text { Bedah }\end{array}$ & 1,3 & 1,4 & 1,3 & 1,3 & 5,3 & 1,3 & $\begin{array}{l}\text { Bekas } \\
\text { digunakan }\end{array}$ \\
\hline 6 & $\begin{array}{l}\text { Ruang } \\
\text { Perinatologi }\end{array}$ & 1,6 & 1,3 & 1,4 & 1,3 & 5,6 & 1,4 & $\begin{array}{l}\text { Bekas } \\
\text { digunakan }\end{array}$ \\
\hline 7 & $\begin{array}{l}\text { Ruang } \\
\text { Gardenia/Anak }\end{array}$ & 1,5 & 1,5 & 1,4 & 1,3 & 5,7 & 1,4 & $\begin{array}{l}\text { Bekas } \\
\text { digunakan }\end{array}$ \\
\hline 8 & $\begin{array}{l}\text { Ruang } \\
\text { Laboratorium }\end{array}$ & 1,9 & 1,3 & 1,4 & 1,5 & 6,1 & 1,5 & $\begin{array}{l}\text { Bekas } \\
\text { digunakan }\end{array}$ \\
\hline 9 & Kamar Operasi & 1,6 & 1,7 & 1,2 & 1,3 & 5,8 & 1,4 & $\begin{array}{l}\text { Bekas } \\
\text { digunakan }\end{array}$ \\
\hline 10 & $\begin{array}{l}\text { Ruang VIP } \\
\text { Dewasa }\end{array}$ & 1,4 & 1,4 & 1,4 & 1,5 & 5,7 & 1,4 & $\begin{array}{l}\text { Bekas } \\
\text { digunakan }\end{array}$ \\
\hline $\begin{array}{l}\text { Jur } \\
\text { mir }\end{array}$ & $\begin{array}{l}\text { lah }(\mathrm{Kg}) \text { per } \\
\text { ggu }\end{array}$ & 16,60 & 15,10 & 14,00 & 13,8 & 59,5 & 14,8 & \\
\hline $\begin{array}{l}\mathbf{R a} \\
(\mathbf{K g}\end{array}$ & $\begin{array}{l}\text { rata ruangan } \\
\text { per minggu }\end{array}$ & 1,66 & 1,51 & 1,4 & 1,38 & 5,95 & 1,48 & \\
\hline
\end{tabular}

Sumber. Data primer (2019)

Data pada Tabel 4 menunjukkan bahwa ruangan penghasil limbah medis padat kasa tertinggi selama 4 minggu terdapat pada ruang bedah dengan nilai total $6,9 \mathrm{~kg}$. Sedangkan ruang penghasil limbah medis padat kasa terendah dengan nilai $5,3 \mathrm{~kg}$ terdapat pada ruangan poli bedah.

Peningkatan jumlah limbah kasa pada setiap unit ruangan umumnya adalah ruangan yang banyak menangani pasien yang mengalami luka, baik luka karena hasil operasi maupun luka karena faktor lain. Penggunaan kasa sebagai pembalut luka, sangat memungkinkan tingginya limbah medis padat yang dihasilkan dari aktivitas pelayanan rumah sakit, dan limbah kasa akan mempengaruhi limbah yang dihasilkan dan limbah ini sangat berhubungan dengan perkiraaan jumlah tempat tidur yang dimiliki oleh rumah sakit. Penggunaan kasa umumnya adalah sebagai pembalut pada luka dan merupakan salah satu teknik yang paling sering digunakan. Tinggi dan 
rendahnya penggunaan kasa per unit ruangan, sangat ditentukan oleh pelayanan medis yang diberikan oleh perawat.

Limbah kasa termasuk dalam golongan $\mathrm{C}$ dan berdasarkan jenisnya merupakan limbah infeksius karena terkontaminasi dengan sumber infeksi seperti darah, cairan tubuh, urine dan lain sebagainya. Pengelolaan limbah medis padat jenis kasa dapat dilakukan dengan pengumpulan pada sumber penghasil limbah, yang dimasukkan dalam kantong plastik berwarna kuning pada tempat penghasil limbah, pengangkutan, penyimpanan dan pemusnahan menggunakan insenerator (Rumah Sakit Umum Daerah Manokwari, 2015).

Berdasarkan hasil wawancara yang dilakukan, diketahui bahwa penanganan limbah padat kasa dengan melakukan penampungan sementara sebelum dimusnahkan menggunakan insenerator, sama halnya dengan penanganan pada jarum dan botol. Kasa yang telah digunakan juga merupakan sumber penghasil patogen yang berasal dari sisa pengobatan seperti luka karena telah terkontaminasi dengan darah pasien yang mengandung virus, misalnya hepatitis B dan C, bahkan penularan HIV (Fitria, 2010).

\section{Total Limbah Medis Padat Berdasarkan Unit Ruangan}

Berdasarkan pengamatan yang dilakukan terhadap limbah medis padat pada 10 unit ruangan di RSUD Manokwari, diketahui bahwa limbah medis padat yang banyak ditemukan adalah jenis limbah medis padat berupa jarum, botol dan kasa. Hal ini disebabkan karena proses penangan pasien pada 10 unit ruangan ini adalah injeksi, pembersihan luka dan pergantian infus, sehingga ketiga jenis limbah padat ini lebih medominasi hasil limbah dari pelayanan medis di RSUD Manokwari. Unit ruangan dan pasien terhadap limbah medis padat yang dihasilkan selama penelitian berlangsung seperti pada Gambar 1.

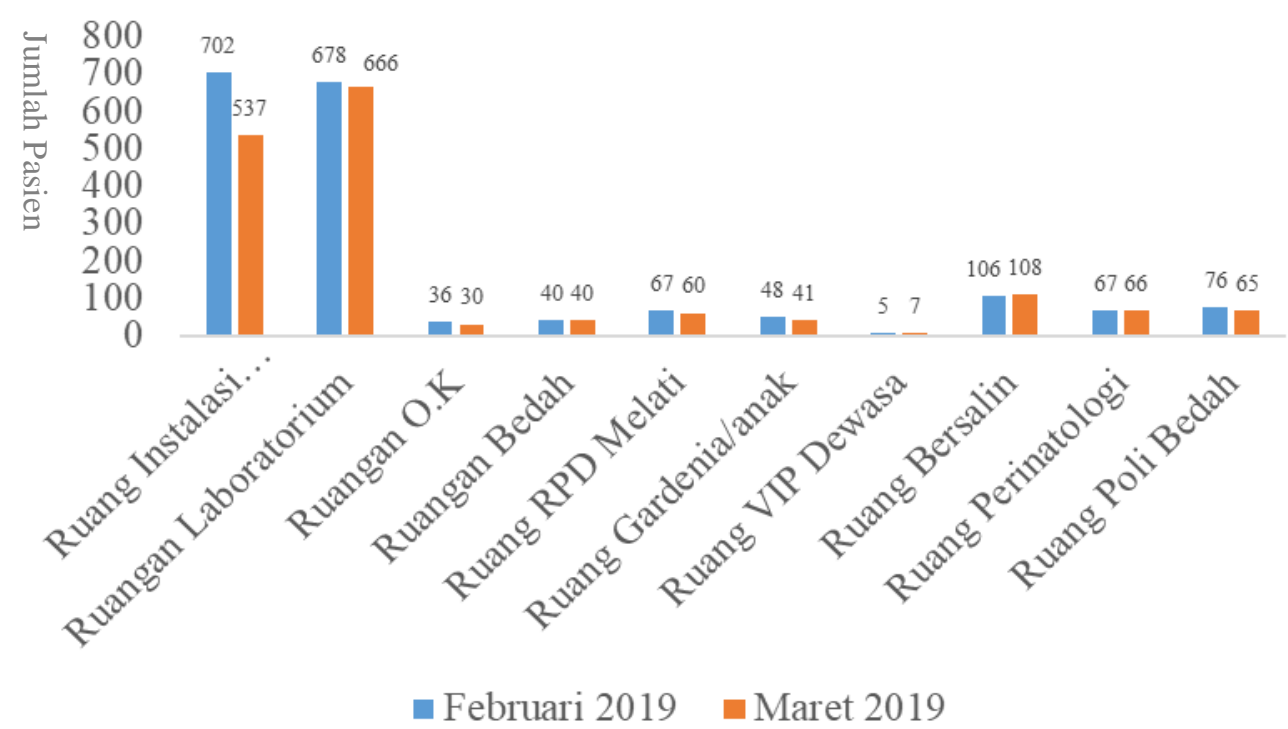

Gambar 1. Jumlah Pasien Per Unit Ruangan di RSUD Manokwari

Berdasarkan data yang diperoleh, diketahui bahwa selama bulan Februari hingga Maret 2019 terjadi peningkatan pasien yang cukup beragam per unit ruangan. Pada Februari 2019 ruang Instalasi Gawat 
Darurat (IGD) di RSUD Manokwari memiliki jumlah pasien yang cukup tinggi yaitu sebanyak 702 pasien, sedangkan jumlah pasien terendah yaitu pada ruang VIP Dewasa yang menangani sebanyak 5 pasien. Jumlah pasien tertinggi pada Meret 2019 di ruang laboratorium yang menangani pasien sebanyak 666 pasien dan terendah di ruang VIP selanjutnya tidak dapat digunakan lagi sehingga menghasilkan volume timbulan limbah sangat banyak. Hal tersebut juga dipertegas oleh Askarian, (2004) bahwa faktor yang memengaruhi volume limbah medis yang dihasilkan rumah sakit antara lain tingkat hunian (Bed Occupancy rate/ BOR), jenis tindakan medis perawatan yang diberikan dan jumlah kunjungan pasien. Volume limbah medis padat yang terkecil berasal dari kasa. Kecilnya volume penggunaan kasa disebabkan karena kasa umumnya hanya digunakan sebagai pembalut luka ataupun pada penggunaan yang khusus.

\section{Tahapan Pengelolaan Limbah Medis Padat di RSUD Manokwari.}

Pengelolaan limbah medis padat di RSUD Manokwari dimulai dari pemilahan, pengumpulan, penampungan serta pemusnahan/pembakaran secara umum telah mengikuti SOP yang dikeluarkan oleh pihak RSUD Manokwari. Walaupun demikian belum sepenuhnya petugas mengikuti SOP tersebut atau mengacu pada Kepmenkes RI. 1204/ MENKES/SK/X/2004. Oleh karena itu, dapat memungkinkan penularan penyakit maupun pencemaran lingkungan dan gangguan kesehatan bagi perawat, petugas kebersihan, pasien maupun pengunjung dan masyarakat secara umum. Tahapan pengelolaan yang telah dilakukan oleh RSUD Manokwari terdiri dari :

\section{Proses pemilahan}

Proses pemilahan limbah medis padat di setiap ruangan penghasil limbah medis setiap hari dikerjakan oleh perawat atau petugas kesehatan yang bertugas pada saat itu. Sistem pemilahan dilakukan berdasarkan limbah medis dan non medis. Tempat limbah diberikan label-label sehingga perawat dan petugas kebersihan/ Cleaning service dapat membuang limbah berdasarkan jenisnya (Widayati, 2017). Berdasarkan observasi di lapangan, tempat limbah medis terdiri dari limbah infeksius dan non infeksius. Limbah infeksius terdiri dari jarum suntik dan pisau bedah yang dibuang pada tempat khusus seperti safety box, sedangkan limbah infeksius lainnya seperti kain kasa, di buang pada tempat tersendiri. Limbah medis non infeksius seperti botol infus, botol obat di buang pada tempat tersendiri juga. Proses pemilahan untuk masing-masing ruang belum sesuai dengan Kepmenkes RI.1204/ MENKES/SK/X/2004 disebabkan pada setiap ruang terdapat dua jenis tempat limbah yaitu limbah infeksius dan non infeksius. Berdasarkan Kepmenkes RI.1204/ MENKES/SK/X/2004 seharusnya limbah rumah sakit dipisahkan menurut limbah infeksius, patologi, farmasi, benda tajam dan sitotoksis.

\section{Proses pengumpulan}

Proses pengumpulan limbah medis dilakukan setiap hari oleh dua orang petugas kebersihan yang dikumpulkan dari 10 ruangan penghasil limbah medis dengan tujuan agar limbah medis tidak menumpuk dan menjadi sumber penyakit. Berdasarkan hasil observasi di lapangan pada tahapan pengumpulan sudah dilakukan dengan cara mengambil limbah medis padat dari proses pemilahan di setiap ruangan dan diketahui masih terdapat 
limbah medis padat yang bercampur dengan limbah medis padat lainnya, sementara limbah tajam seperti bekas jarum suntik dikumpulan menggunakan safety box dan modifikasi ember cat yang di lapisi kantong plastik kuning. Hal ini sesuai dengan Kepmenkes RI.1204/MENKES/SK/X/2004 tentang persyaratan kesehatan lingkungan rumah sakit yaitu benda tajam sebaiknya ditampung menggunakan safety box atau terbuat dari bahan yang kuat. Penggunaan bahan yang kuat dalam pengumpulan digunakan agar benda tajam tidak dapat menembus ke bagian luar karena apabila benda tajam seperti jarum suntik menembus tempat pengumpulan tentunya akan menyebabkan tertusuk kepada petugas kebersihan/Cleaning service yang menangani limbah medis tersebut.

\section{Proses penampungan}

Proses penampungan limbah medis padat dilakukan setiap hari oleh dua orang petugas kebersihan. Limbah medis dikumpulkan dari setiap kantong plastik dan dimasukkan ke dalam wadah/ ember yang lebih besar. Berdasarkan observasi di lapangan terlihat bahwa petugas kebersihan/Cleaning service mengumpulkan terlebih dahulu semua limbah medis padat dari setiap ruangan penghasil limbah. Kemudian limbah tersebut dimasukan ke dalam tempat penampungan limbah sementara yang besar. Berdasarkan Kepmenkes RI.1204/MENKES/SK/X/2004, penampungan sementara selambatlambatnya dilakukan selama 24 jam di rumah sakit yang mempunyai insenerator, namun apabila tidak memiliki mesin insenerator maka bekerja sama dengan rumah sakit lain dan pemusnahan selambat-lambatnya 24 jam apabila disimpan pada suhu ruang. Namun pada penelitian ini, berdasarkan hasil observasi limbah medis padat disimpan lebih dari 24 jam, dimana pemusnahan limbah dilakukan dua kali dalam satu minggu.

\section{Proses pengangkutan}

Pada tahap ini tidak terlihat adanya proses pengakutan limbah medis padat menggunakan mobil khusus atau kendaraan lain, dikarenakan posisi mesin insenerator berada di lokasi penyimpanan pada lingkungan RSUD Manokwari. Berdasarkan hasil observasi di glapangan terlihat bahwa proses pengankutan mulai dari penampungan limbah sementara lansung diangkut ke tempat insenerator, disebabkan posisi insenerator berada bersamaan di ruang penyimpanan.

\section{Tahap pemusnahan/Pembakaran}

Tahap kelima adalah
pemusnahan dan pembakaran akhir
limbah medis padat yang dilakukan oleh satu petugas insenetor. Pada saat pengamatan proses pemusnahan dan pembakaran akhir dilakukan dua kali dalam satu minggu. Mesin insenerator yang digunakan oleh petugas pengelola limbah untuk pemusnahan/pembakaran limbah medis padat dengan kapasitas 50 $\mathrm{kg}$ dan suhu $800^{\circ} \mathrm{C}$. Berdasarkan observasi di lapangan pada tahap pemusnahan/pembakaran ditemukan limbah yang dihasilkan sebanyak 6-7 kg sehari, sehingga tidak sesuai volume insenerator berkapasitas $50 \mathrm{~kg}$ yang saat ini digunakan oleh pengelola limbah.

$$
\text { Hasil observasi juga }
$$

menunjukkan bahwa sisa hasil pembakaran atau residu belum sepenuhnya menjadi abu, masih terdapat sisa-sisa jarum suntik maupun pecahan kaca yang selanjutnya di buang ke sumur tua yang terdapat di lingkungan Rumah Sakit, sehingga hal ini dapat mencemari lingkungan di sekitar RSUD Manokwari. Oleh sebab 
itu petugas kebersihan melakukan pemusnahan/pembakaran dua kali dalam satu minggu. Berdasarkan Kepmenkes RI No1204/Menkes/Sk/X /2004 dilakukan pemusnahan/pembakaran pada musim panas paling lama 24 jam sedangkan musim hujan paling lama 48 jam. Dari hasil pengamatan di lapangan ditemukan waktu penyimpanan limbah lebih dari 48 jam yang disesuaikan dengan jumlah limbah medis padat yang dihasilkan.

\section{KESIMPULAN}

Karakteristik limbah medis padat di RSUD Manokwari, dapat dilihat dari volume timbulan limbah medis padat yang dihasilkan pada minggu I lebih banyak dibandingkan minggu II, III dan minggu IV, dengan jumlah limbah tertinggi adalah jarum, botol dan kasa.

Pengelolaan limbah medis padat belum sepenuhnya mengikuti SOP dan Kepmenkes RI Nomor 1204/Menkes/SK/X/2004 karena masih adanya limbah medis padat yang tercampur antara jarum, botol dan kasa. Kantong plastik yang digunakan untuk memisahkan limbah medis padat tidak sesuai dengan SOP pengelolaan limbah medis padat. Sarana dan prasarana pengelolaan limbah medis padat telah disediakan oleh rumah sakit namun khusus untuk insenerator hanya memiliki suhu maksimum pada kisaran $800^{\circ} \mathrm{C}$ sehingga masih terdapat residu pembakaran yang belum sepenuhnya musnah.

\section{Saran}

Perlu evaluasi SOP pengelolaan limbah medis padat yang mengacu pada Permenkes No 7 Tahun 2019 Tentang Kesehatan Lingkungan Rumah Sakit, selain itu penelitian selanjutnya perlu menggunakan acuan terbaru yaitu menurut Permenkes No 7 Tahun 2019
Tentang Kesehatan Lingkungan Rumah Sakit ataupun peraturan pemerintah lainnya tentang kesehatan lingkungan, sehingga dapat memperoleh hasil penelitian dengan acuan yang terbaru.

Penelitian selanjutnya juga perlu menggunakan metode dan teknik pengambilan data yang lebih baik sehingga data yang diperoleh juga lebih akurat.

\section{DAFTAR PUSTAKA}

Askarian, M., Vakili, M., \& Kabir, G. (2004) Hospital waste management status in university hospitals of the Fars province, Iran, International Journal of Environmental Health Research, 14:4, 295-305, DOI: $10.1080 / 0960312041000172563$ 0

Biro Umum dan Setjen Depkes RI. (2003). Lokakarya penanganan limbah tajam. (http://www.depkes.go.id) diakses pada 08 Agustus 2020.

Chotijah, S., Muryanti, D.T., dan Mulyan Kota Si, T. (2017). Implementasi kebijakan pengelolaan limbah rumah sakit di rumah sakit Islam Sultan Agung Kota Semarang. Humani (3) : 223-236

Departemen Kesehatan RI. (2004). Kepmenkes1204/MENKES/SK/ $\mathrm{X} / 2004$. Persyaratan kesehatan lingkungan rumah sakit. Dirjen PPM dan PL Depkes RI. Jakarta.

Djohan, A.J., dan Halim, D. (2013). Pengelolaan limbah Rumah Sakit. Salemba Medika. Jakarta.

Fitria, N.C. (2010). Kesehatan dan keselamatan kerja di rumah sakit. Profesi. Edisi 06 Februari 2016. diakses pada 21 Juli 2020.

Hapsari. (2010). Analisis pengelolaan sampah dengan pendekatan 
sistem di RSUD dr. Moewardi Surakarta. Tesis Undip. Semarang. diakses pada 21 Juli 2020

Jumriah, Tjolli, I., \& Martanto, E. A. (2021). Persepsi, Sikap dan Partisipasi Keluarga Pasien/Pengunjung dalam Menciptakan Kebersihan Lingkungan Rumah Sakit di Kabupaten Manokwari Provinsi Papua Barat. Cassowary, 4(2), 119-132.

https://doi.org/10.30862/casssow ary.cs.v4.i2.60

Keputusan Menteri Negara Kesehatan RI. (2004) Nomor: 1204 /MENKES/SK/X/2004 tentang persyaratan kesehatan lingkungan Rumah Sakit. Dirjen PPM dan PL Depkes RI. Jakarta.

Nursamsi., Thamrin., dan Efizon, D. (2017). Analisis pengelolaan limbah medis padat Puskesmas di Kabupaten Siak. Dinamika Lingkungan Indonesia (4) : 8798.

Rumah Sakit Umum Daerah Manokwari. (2015). Standard operating procedures. IPSRS dan Sanitasi. Rumah Sakit Umum Daerah Manokwari. Manokwari.

Rusdiana, H.M., Kusnanto, H., dan Padmawati, R.S. (2014). Kebijakan pembakaran limbah medis padat dengan insenerator di RSUD dr. H. Moch Ansari Saleh Banjarmasin. Jurnal Kebijakan Kesehatan Indonesia (3) : 70-89

Sitopu, C.S. (2017). Sistem Pengelolaan sampah padat medis Rumah Sakit Umum Daerah Sultan Sulaiman Kecamatan Sei Rampah. Politeknik Kesehatan. Medan.
Standar Nasional Indonesia (SNI). (2017). 321764650SNI-1994 (http://www.academia.edu) diakses pada 21 Juli 2020.

Sulistionigsih, W. (2014). Analisis pelaksanaan standar operating procedure (SOP) penyadapan darah donor terhadap kualitas trombosit di unit transfus idarah PMI kota Yogyakarta. Politeknik Kesehatan Bhakti Satya Indonesia. Yogyakarta.

Van Tuong, P., Phuong, T. T. M., Anh, B. T. M., \& Nguyen, T. H. T. (2017) Assessment of Injection safety in Ha Dong General Hospital, Hanoi, in 2012 (https://doi.org/10.12688/f1000r esearch.1399.1)

Wawan, D. (2010). Teori pengukuran pengetahuan dan sikap perilaku manusia. Nuha Medika. Jogyakarta.

Wicaksana A. (2002) Penyakit Akibat Kerja di Rumah Sakit dan Pencegahannya. Jurnal Cermin Dunia Kedokteran No. 134. Jakarta: PT. Kalbe Farma. 2002.

WHO. (2005). Pengelolaan limbah layanan kesehatan. Safe management of waste from health care Aktivity. Jakarta

Widayati, W. (2017). Hubungan antara pengetahuan dan sikap dengan tindakan petugas kesehehatan dalam upaya pengelolaan sampah medis di Rumah Sakit Griya HusadaMadiunTahun 2017. Skripsi. Stikes Bhakti Husada Madiun. Madiun.

Widiartha, K.Y. (2012). Analisis sistem pengelolaan limbah medis Puskesmas di Kabupaten Jember. Kesehatan Lingkungan dan Keselamatan Kerja Universitas Jember. Jember.

Zuhriyani. (2019). Analisis sistem pengelolaan limbah medis padat 
berkelanjutan di Rumah Sakit

Umum Raden Mattaher Jambi.

Jurnal Pembangunan

Berkelanjutan (1) : 55-63. 